rev.relac.int.estrateg.segur.11(2):161-185,2016

\title{
THE NEW HIDEOUT OF COCKROACHES? THE EXPANSION OF THE MEXICAN ORGANIZED CRIME IN THE NORTHERN TRIANGLE OF CENTRAL AMERICA*
}

\author{
Esteban Arratia Sandoval**
}

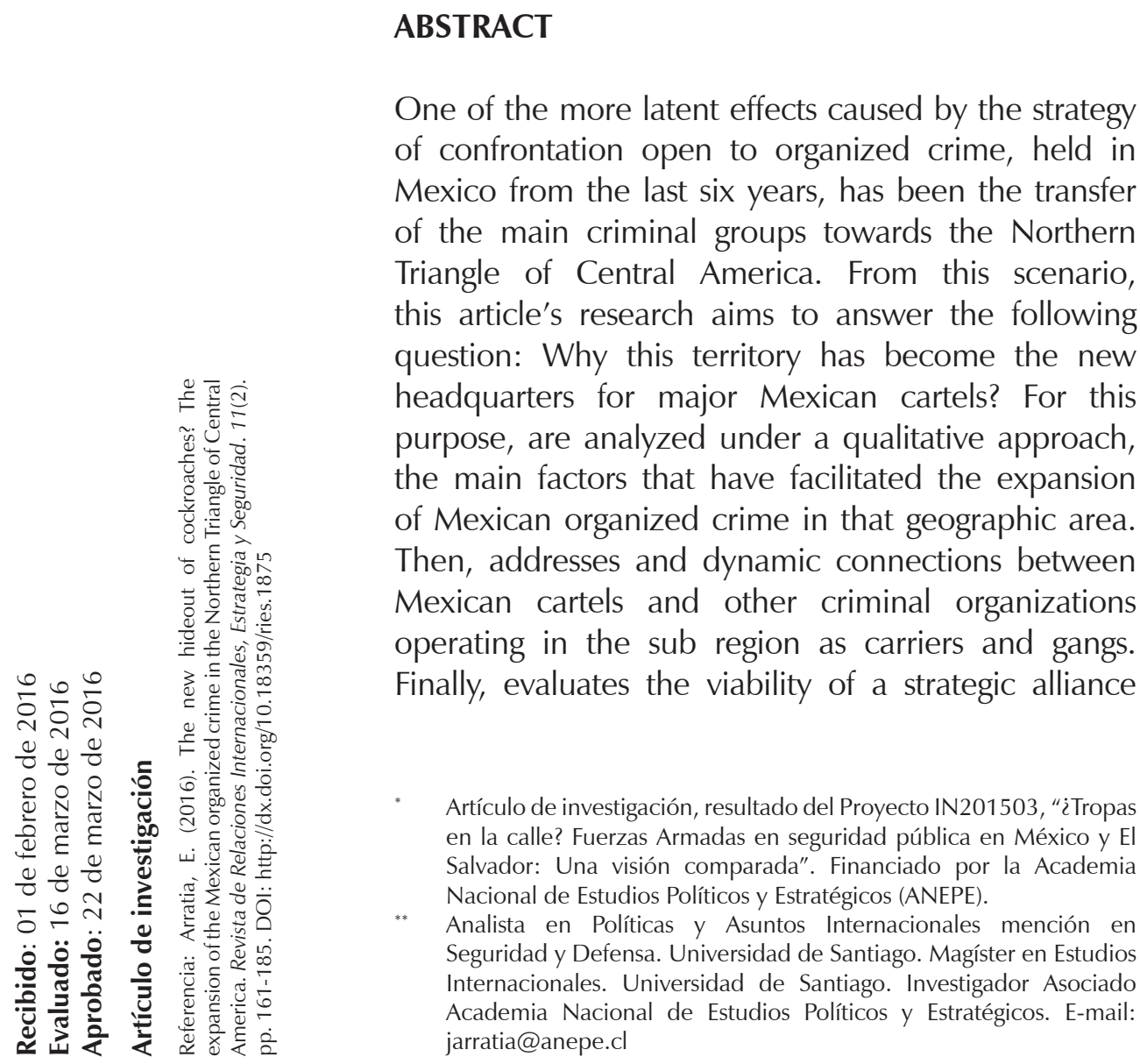


between two actors with greater preponderance in the criminal scene of the area: Los Zetas and Mara Salvatrucha. The paper concludes that, by its geographical location, its porous borders, its weakness institutional and growing sophistication of local criminal groups - transportistas- and gangs, the Northern Triangle of Central America provides spacious opportunities for Mexican drug trafficking expansion

Keywords: Central America; Drug traffic; Mexico.

\section{¿EL NUEVO ESCONDITE DE LAS CUCARACHAS? LA EXPANSIÓN DEL CRIMEN ORGANIZADO MEXICANO EN EL TRIÁNGULO NORTE DE AMÉRICA CENTRAL}

\section{RESUMEN}

Uno de los efectos más latentes ocasionados por la estrategia de confrontación abierta al crimen organizado, mantenida en México desde el sexenio pasado, ha sido el traslado de los principales grupos criminales hacia el Triángulo Norte de América Central. A partir de ese escenario, el presente artículo de investigación tiene como objetivo responder la siguiente pregunta: ¿Por qué aquel territorio se ha transformado en el nuevo centro de operaciones para los principales carteles mexicanos? Para tal efecto, se analizan, bajo un enfoque cualitativo, los principales factores que han facilitado la expansión del crimen organizado mexicano en esa área geográfica. Luego, se abordan las conexiones y dinámicas entre los carteles mexicanos y otras organizaciones criminales operativas en esa subregión como los transportistas y maras. Finalmente, se evalúa la viabilidad de una alianza estratégica entre dos actores con mayor preponderancia en la escena criminal de aquella zona: Los Zetas y Mara Salvatrucha. El trabajo concluye que, por su ubicación geográfica, sus fronteras porosas, su debilidad institucional y creciente sofisticación de sus grupos criminales locales - transportistas - y maras, el Triángulo Norte de Centroamérica ofrece amplias oportunidades para la expansión del narcotráfico mexicano.

Palabras clave: Centroamérica, México, narcotráfico.

\section{O NOVO ESCONDERIJO DE BARATAS? A EXPANSÃO DO CRIME ORGANIZADO MEXICANO NO TRIÂNGULO NORTE DA AMÉRICA CENTRAL}

\section{RESUMO}

Um dos efeitos mais latentes causados pela estratégia de confronto aberto com o crime organizado, realizado no México nos últimos seis anos, tem sido a 
transferência dos principais grupos criminais para o Triângulo Norte da América Central. Neste cenário, a pesquisa deste artigo destina-se a responder à pergunta seguinte: Por que este território tornou-se o novo centro de operações para os principais grupos de crimes organizados mexicanos? Para este fim, são analisados sob uma abordagem qualitativa, os principais fatores que facilitaram a expansão do crime organizado nessa área geográfica. Em seguida, conexões e dinâmica entre as organizações criminais mexicanas e outras organizações criminosas que operam nesta sub-região como portadores e "maras" é abordada. Finalmente, avalia a viabilidade de uma parceria estratégica entre dois personagens com maior preponderância na cena criminal da área: Los Zetas e Mara Salvatrucha. O jornal conclui que, pela sua localização geográfica, suas fronteiras porosas, sua fraqueza institucional e crescente sofisticação de seus grupos criminosos locais transportadoras - e maras, o Triângulo Norte da América Central oferece amplas oportunidades para a expansão do tráfico de drogas mexicano.

Palavras-Chave: América Central; México; Tráfico de Droga.

\section{Introduction}

The War on Drugs driven Mexico during the government of Felipe Calderon (2006-12) it has been identified as the main catalyst for the movement of organized crime into the Northern Triangle of Central America, Guatemala, Honduras and El Salvador-producing the so-called cockroach effect ${ }^{3}$ as shown in Figure 1. This situation can be interpreted in several ways: From the standpoint of national security, migration caused by this criminal strategy to combat drug trafficking organizations can be considered a success because it forced the drug organizations move much of its operations outside the Mexican territory and also caused a change in the corridors of access to the US market. However, at the neighborhood level it can be classified as a failure because it passed a security of a State other border unprepared to fight criminal gangs or illegal activities displaced from the sending country -Mexico-. In short, the cockroach effect towards the north Central American sector demonstrates the militarized

According to Bruce Bagley, the cockroach effect occurs when criminal organizations to avoid detection by the authorities after the light has been lit on them move from one municipality to another, from one city to another, from one country to another; or from one region to another in search of a better context to set and carry out their criminal activities. See: Garzón, 2013, p.12 
approaches can become effective in their task of combating transnational organized crime at the state level, but not at the sub regional level (Servitja Roca, 2012).

Figure 1. Central America: Transit and conflict area.

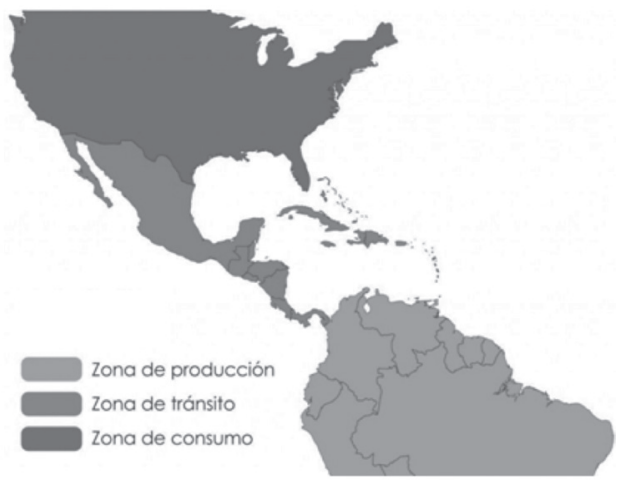

Source: Extracted from Pérez, 2014.

Thus, the use of the armed forces in some states of Mexico, especially border, exerted pressure on organized crime operating in them. This means that the more military presence there, unless border crossings are enabled for the transit of illicit trafficking and this causes a bottleneck, i.e. the convergence of routes within a few access roads and the resulting clash of groups to control them or facilitate the income from their illicit products. To increase the human and material costs of drug trafficking along the northern border of Mexico, as well as the degree of danger on the roads because of violence generated in disputes - added to the increasing US pressure to intercept Caribbean routes-, posters had to seek alternative routes to Mexico as the traditional gateway to North America, generating incentives for drug racking be relocated on the southern border, using Northern Triangle nations as a transit point for the purpose to control the route in its entirety, "turning this area into a bottleneck through which almost all the cocaine coming from South America, particularly in Bolivia, Colombia and Peru and destined for the United States" (Dudley, 2012a, p.10) as illustrated by the data given in Figure 2

Figure 2: Tons of cocaine seized in Central America (2006-12)

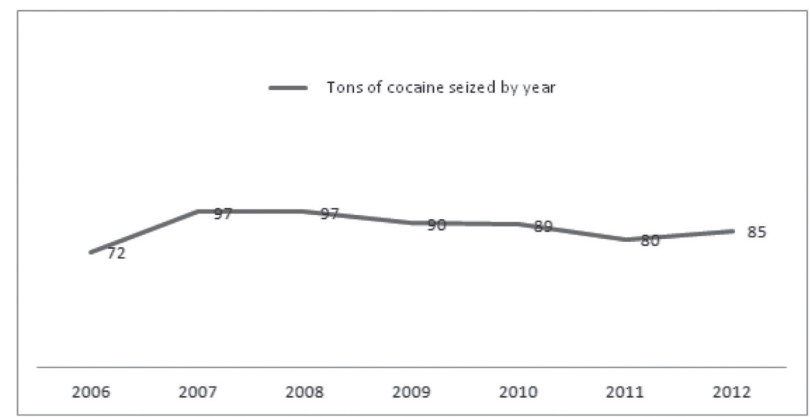

Source: Own production from UNODC, 2012. 
The main Mexican cartels often seek a path of least resistance for their criminal activities, and in that sense it seems that the Northern Triangle has become a strategic point for the following reasons:

\section{Geographic location}

For be between largest cocaine producer -Colombia- and the largest consumer of it the worldwide - United States-.

Because of its proximity to Mexico with signs that control traffic routes it has begun to be used as drug store them.

For the vast expanse of coast which provide that avails for the arrival of shipments of illicit trafficking by sea.

By owning spaces and border regions lacking or absent state control points rule of law that remain unidentified blind-along most of its length. In addition, official adjacent crossings are few, far between and do not have the necessary equipment or to deter illegal traffic of drugs, arms and people staff (Ramsey, 2012)

\section{Institutional weakness}

By having a number of structural deficits that encourage the establishment of a relationship between organizations drug traffickers and governments based on a transactional paradigm, i.e., logic of exchange between government officials or political authorities and criminal groups which is a network of institutionalized corruption replaced the rule of law ${ }^{4}$. Thus, "the exchanges include admission fee for loads of cocaine in exchange for money; support for a political campaign in exchange for protection for criminal activities; loyalties changing in parliament regarding situations related to organized exchange for luxury coastal properties partisan crime; court decisions in cases of neglect or deliberate stalling of them in exchange for economic benefits; access to prisons for the killing of key witnesses in exchange for thousands of dollars; or payments to police officers to commit murder" (Farah, 2013, p.91).

These links based on a high degree of tolerance by the State -fighting illicit economies marginally or inefficiently in best cases- are needed to avoid disruption of the development of illicit operations by the authorities. The

Chabat poses that criminal groups may have different types of organization depending on the illicit economy developed and the relationship established with the State. Thus, the relationship between the State and the criminal organization can go through three phases: predatory (low capacity, low relative importance), parasitic (interaction limited between the State and criminals) and finally symbiotic (State structures work to benefit criminal organizations). See: 2008, p.4 
result of this is "the failure of the state as an entity on many levels, which are actively covered by transnational organized crime"(Farah, 2013, p.92). In sum, States will determine the shape or type of the criminal organization that operates and strengthened in a given territory (Garzón Vergara, 2013).

\section{Production costs}

The need that Mexican cartels have to be close production centers, which influences the acquires value a substance in the Mexican market against price recorded in Central America. This means that the closer the Aztecs criminal organizations where drugs are produced, they can buy cheaper and better your profits. For example, "the price level reaching cocaine in Mexico City -US \$ 18,000/kg- compared to the price in Guatemala -US \$12,000 / kg-provides incentives for purchase in the second region and subsequent sale on the first, without doubt influencing drug traffickers to move to the southern border" (Dudley, 2012a, p.11).

\section{The new coordinates of violence}

According to the report Transnational Organized Crime in Central America and the Caribbean: An evolving threats, published by the United Nations Office on Drugs and Crime -UNODC- in 2012, the Pacific Cartel and Los Zetas have not only taken to Northern Triangle $90 \%$ of its operations to traffic cocaine into the United States (see Figure 3), but their battles for plazas ${ }^{5}$ control located in the sub region, which are fought by local criminal organizations co-opted by their Mexican counterparts, these being the main problem disputes crime that plagues this area of the subcontinent (Martinez, 2013).

Thus, these nations who survived political violence armed-conflicts and/ or military repression during the Cold War now suffer the vicissitudes of a war between organized crime. Making situation that Guatemala, Honduras and El Salvador in the most violent countries in the world, high rates of homicides recorded realize that classification (see Figure 4).

The link between drugs and criminal violence in the Northern Triangle is different to that experienced in Mexico due to the complex interaction of various criminal actors with history, activities and modus operandi traditionally different. Thus, those in the Northern Triangle criminal groups

The plaza has been used to describe the territories where they traffic drugs along the border of the United States with Mexico. Most of the major cartels were associated to a specific place, usually focused on one of the two twin border cities. Control the plaza entails an important flow of revenue associated. See: UNODC, 2012, p.19 
Figure 3: Influence of the Pacific Cartel and Los Zetas in Central America

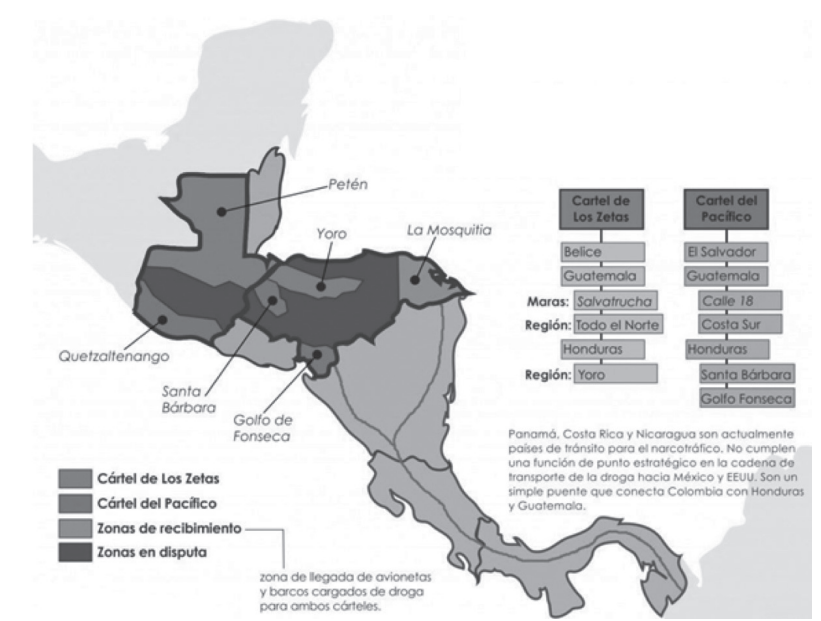

Source: Extracted from Pérez Ventura, 2014.

Figure 4: Homicide rate per every 100,000/room Northern Triangle (2006-14).

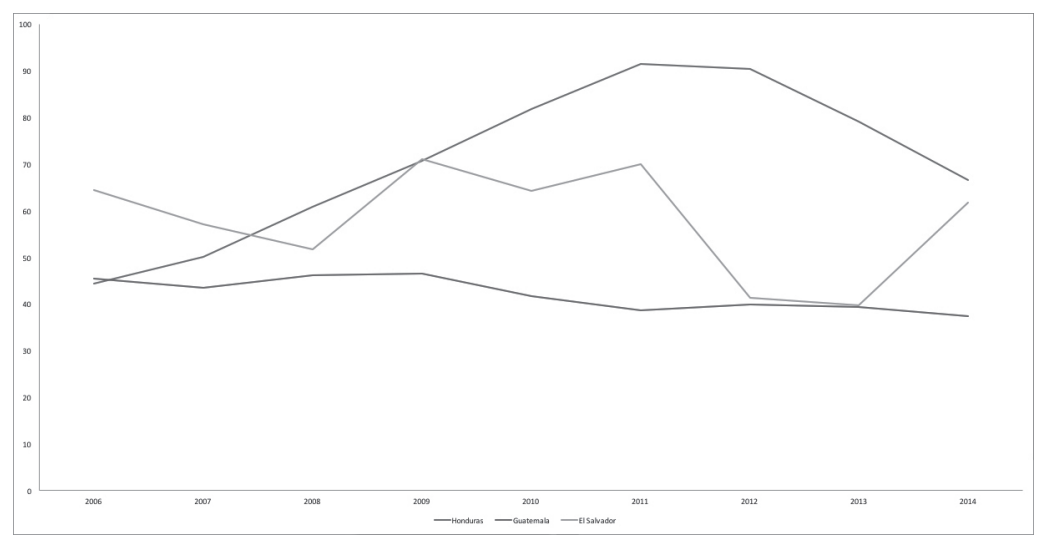

Source: Own production from ACAPS, 2014

can be classified as Managers and Transportistas:

The managers are the ones who control the route and have the power of decision. This role is exercised in full by the Mexican cartels that are set in the sub region.
These product obtained illicit traffic directly from the source markets. For reception, storage, transport and protection to the final market, they hire local groups monitored by them known as transportistas, in turn, can act as dealers in the local market as part of their work is paid 
with the product trafficked. (Servitja

Roca, 2012, p.9)

Normally the Sinaloa Cartel and Los Zetas conduct their affairs in the sub region through local allies mostly. Thus, members of these two rivals drug cartels "usually they negotiate agreements, with surprising that the Mexican cartels are involved directly in operations carried out abroad"(Farah, 2013, p.98). Emerging conflict between the two models of transnational organized crime in accordance with their interests in the Northern Triangle: Business model Sinaloa Cartel- and territorial model - Los Zetas-. Indeed, each country has experienced changing degrees of cooperation between non-state actors -managers and transportistas, as detailed below.

\section{Guatemala}

According to the report Guatemala: Drug trafficking and violence prepared by the International Crisis Group, the outbreak of the Mexican cartels is the latest in a vicious circle of violence and institutional failure episode. Geography has made this country -located at the north end of Central America- "in one of the busiest intersections for illicit drugs. Cocaine and now the ingredients for synthetic drugs entering by air, land and sea. Hence it follows Mexico en route to the United States. Added to this is the cool highlands offer ideal climate poppy cultivation.
Because of lax regulations and a long history of smuggling, weapons abound. An impoverished and underemployed population is a good source of recruits" (ICC, 2011, p.3).

The Sinaloa Cartel is already operating in the Pacific region in Guatemala. Indeed, this criminal organization has established strong links with major trasportistas Guatemala: The Mendozas -based in the northern province of Petén apparently you have provided the Mexican drug cartel for more than a decade. The strategy used by the Sinaloa Cartel to expand its influence in the neighboring country is mainly based on a business model locally "as a creator of employment opportunities, health care provider, even assuming the role of government to eliminate small criminal groups in areas under their control" (TNI,2012, p.9). This action is very different from Los Zetas, "who they are based in a vertical structure and brute force, which may explain the success of the Sinaloa Cartel to prevent Los Zetas take control of the province of Huehuetenango" (TNI, 2012, p.10) crucial area for drug trafficking.

Meanwhile, Los Zetas have evolved to the point of becoming one of the greatest threats to domestic security from their arrival in Petén in 2007, when they established an alliance with the Guatemalan trafficker Horst Walther Overdick. They have even been identified as the biggest criminal organization with nationwide 
presence because approximately $75 \%$ of the Guatemalan territory it controls (Dudley, 2013a).These explosive increases in its degree of influence tend to be explained in two ways: First, obey the successful tactics of recruitment among members of local criminal organizations whose leaders have been jailed. Furthermore, local criminal elements operate according to logic incompatible with Los Zetas and, therefore, prevent this group to recruit local high-level positions within the organization. However, as is well known Los Zetas, whose origin is in a group of defectors from the former Airmobile Special Forces Group who were initially hired as enforcers for the Gulf Cartel in the 90's- have established links with the former commands Kaibiles unit of Special Forces of Guatemala. These former officers have helped this Mexican cartel providing intensive military training in logistics and heavy weaponry to new members, which fits perfectly with the military perspective cultivated by Los Zetas. Which seems to be part of a broader strategy consists in recruiting members to reduce costs Kaibiles indoctrination and training as well as for firearms and grenades Guatemalan military (Bargent, 2013).

As in Mexico, Los Zetas were unveiled at the North Triangle for their extreme violence, instead of gradually cultivate community support and bribe officials and local police, they attempted to take control of the drug routes by strength. One example is the slaughter of 29 peasants in the department of Peten in May 2011, an episode that has been interpreted as an attack by the cartel to a local drug dealer operating in this sector.

Currently they exert territorial control over the cocaine trade in the top five provinces -Petén Guatemala, Huehuetenango, Quiché, Alta Verapaz and Zacapa- through the band known as The Lorenzanas on a route that crosses the country from the border with Honduras to the border with Mexico as shown in Figure 5. In addition, four other adjacent municipalities with Honduras and with access to the Pacific coast-Chiquimula, Jutiapa, Jalapa and Santa Rosa were caught by the local group Los Zetas dominant Lions, whose leadership was shot by Mexican drug trafficking organization.

Figure 5:Territorial influence Los Zetas in Guatemala

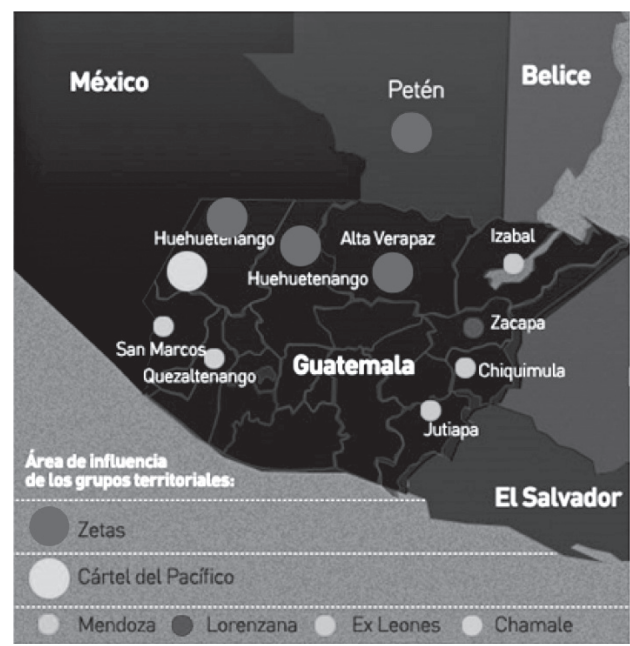

Source: Extracted from Martinez (2013) 


\section{Honduras}

Mexican cartels have participated in the narcotics industry in soil Honduran for at least fifteen years. But after the overthrow of Manuel Zelaya in 2009-and the complete disregard for organized crime by the interim government - served to expand its power at the expense of local groups (TNI, 2012 p.10). Indeed, Honduras has become a major transfer point between Colombian cocaine and Mexican cartels -even it is considered the main airlift for that substance from South America, Venezuela being the starting point-.

An example signal the dismantling of a cocaine laboratory in March 2011, with the capacity to process one ton of cocaine belonging to monthlySinaloa cartel, which is significantly more powerful than its counterpart in Honduras, Los Zetas. In fact, it has been speculated that Honduras has been used by its leader, Joaquin El Chapo Guzman as a hideout after his recent escape (Gagne, 2015a).

Thus, the Sinaloa Cartel has established a transport route to mobilize large amounts of cocaine by air and speedboats between Colombia and Honduras before sending it to the north. The Mosquito Coast, located on the border with Nicaragua lacks state presence so it serves as a refuge for local groups cooperating with the cartel. Such operations are also carried out in other northern provinces as Yoro, Atlantida, Colon and Olancho. Indeed, the Sinaloa cartel controls the production of ecstasy and methamphetaminesspecifically in the department of Olancho- that are shipped to Europe and the United States. There are also reports that shipments of pseudoephedrine a precursor for the production of metanfetaminas- from Asia and Western Europe pass through Honduras under the responsibility of the Mexican criminal group. In that direction, customs officials have reported that the Sinaloa Cartel use land routes that cross the border between Honduras and Guatemala.

While Los Zetas have it has been detected in the four Northern provinces: Ocotepeque, Copan, Colon, and Atlantis (McDermott, 2013). Also, the Mexican cartel has hired former Honduran police officers to provide protection for drug trafficking operations, and help with operations of kidnapping and extortion of migrants, one of the principal illicit activities of this organization drug trafficker $^{6}$. Based on the foregoing,

The brutal psychological tactics associated with the Mexican cartel are becoming increasingly common in this country because they have proven to be effective in the control of the civilian population, as well as the ranks of organizations. See: Parkinson, 2013a 
one can conclude that this criminal group and has not only representatives in Honduras in order to supervise the receipt and transportation of shipments of cocaine from South America, but has established a formal presence translated into military capability.

\section{El Salvador}

Following Bartolomé \& Sampó (2014), the smallest of the Northern Triangle country meets two conditions that make it attractive to Mexican cartels.

First, considering its northern territory -close to the border with Guatemala- has been institutionalized as a meeting place for leaders of criminal organizations not only resolve their differences there, but enjoy impunity needed to design strategies and plans to enable them to carry out their operations. And secondly, the lack of programs to combat money laundering and the dollarization of the economy, currency movements possible from drug trafficking and weapons from there to Europe and the United States. (p.102)

In this country, transportistas are responsible for protecting shipments of cocaine coming out of Colombia and Ecuador, through Central America all the way to Mexico. Thus, the main Salvadoran criminal organizations have strong connections with the Sinaloa Cartel: Texas Cartel -whose network operates in the northwest of the country- and Los Perrones -located in the East and around the region- have links with the West that criminal group Aztec dating back at least to 2002 (Gagne,2015a). Members of both groups are responsible for ensuring that the cocaine smuggled from El Salvador to be transported safely from the Pacific coast to Guatemala or Mexico, where it is delivered to the Mexican drug trafficking organization.

Instead, The Zetas don't yet have an operational presence in El Salvador, so far, have chosen to occasionally send key members located in Guatemala. Although an episode arms trafficking case in 2013 suggests a link between them and the Texis Cartel might constitute a novel criminal synergy, as the local government has increased pressure on the Salvadoran group ${ }^{7}$.

Moreover, the sub regional panorama discussed above allows the following scenarios envisage the short and medium term:

213 anti-tank grenades stolen from the Salvadoran army in a house in the central city of the Congo, as signs of the National Civil Police, were going to be used for the Mexican cartel by a shuttle provided by the Texis Cartel were uncovered in October 2013. This version is plausible considering that the Salvadoran group is known for its transportation services to anyone willing to pay, and is involved with several transnational groups. See: Parkinson, 2013b 
First, from the current stage bipolar-dominated by the Sinaloa Cartel and Los Zetas presence and operations of other Mexican criminal groups smaller in the Northern Triangle seems to have more of a complementary residual and therefore the small drug trafficking organizations could be annexed by the great. In this case, the tactical alliances benefit the Sinaloa Cartel because of its strong commercial orientation in contrast to the military perspective of Los Zetas. However, this does not imply that the Mexican cartels possess such a capability that allows "impose its authority to Guatemalan [Honduran or Salvadoran] criminal because it would require a capacity to control social strength and knowledge of the terrain with only about their area of influence". (Villalobos, 2011a, p.17)

The second possibility would be favorable to small criminal groups, which eventually inherit trafficking routes along with control of drug flows, but its realization will depend largely on two factors: the confrontation between the Sinaloa Cartel and Los Zetas is performed on Mexican soil and the effects of these posters persecution by the Aztecs authorities.

The third scenario would be that the weakening of the Mexican cartels, we could see the strengthening and increasing role of the Central American criminal organizations trafficking networks at the sub regional level. Indeed, leading candidates to take over that role would be the Texis Cartel on Salvadoran ground and Los Mendozas in Guatemalan territory (Fox, 2012). Therefore, the history of drug diffusion linking Colombia with Mexico could be repeated in Central America in light of the relative achievements of the strategy to combat the Aztec government.

In a fourth scenario, the fragmentation of the Mexican cartels rather lead to a market of more plural and fragmented drug that would operate from three fronts-Mexico, Northern Triangle and Colombia. Under the assumption that the higher criminal atomization, greater state control capacity exist, a situation which in principle could be reflected in a greater responsiveness on the part of governments in the sub region.

Finally, another projection is that the Sinaloa Cartel and Los Zetas could reach an agreement on their respective areas of geographical influence advocate a pax mafiosa-. Although the possibility of occurrence is very low because the differences between criminal actors-from the strategic, operational and organizational-angle are simply irreconcilable.

\section{Unexpected convergence? Mexican cartels, Trasportistas and Maras.}

As noted in the previous section the two main Mexican cartels - Sinaloa 
Cartel and Los Zetas- criminal networks have been established in the North Triangle allying with local actors such as transportistas. However, they have also forged ties with cells or cliques of gangs, particularly the Mara Salvatrucha (MS-13) and Barrio 18 (M-18). Now, the question arises: what is the origin and how they have developed these links?

According to Cruz's arrival gangs to the North Triangle during the 90s -product of mass deportation by United StatesIt marked the first transition from one "model of traditional, local, and atomized, an organized, hierarchical and transnational identity model" gang (Santamaría, 2013, p.66). Then, in mid-2000, the adoption of policies hard hand against gangs by Central American governments plus the expansion of drug trafficking networks in the sub region generated a second transition.

Thus, they mutated into a criminal gang mode "farthest from the traditional gang and closer to a model of criminal gang, in which [the gain] extortion and drug dealing has been accentuated as the moving head of these groups through strategic alliances with other criminal organizations" (Santamaría, 2013, p.67) as transportistas. In this regard, it is noteworthy that prison overcrowding caused by the application of these repressive measures against gangs provided contacts necessary for them to enter into such circuits, operating as a facilitator to transition them to new forms of organized crime ${ }^{8}$. Therefore, the strategy to combat gangs in Northern Triangle had an unexpected effect: a growing intersection between the activities of transnational organized crime, local criminal groups and gangs.

However, it is not possible to argue that this new phase necessarily implies lasting agreements between gangs and other criminal organizations as the Northern Triangle it's difficult "establish whether this transition has been collective and consensual manner or if certain cells or gang members who choose to participate in these transnational organized crime networks is rather limited" (UNODC, 2012, p.13). Indeed, gangs face a number of alternatives ranging from joining these criminal groups to directly confront them while "each clica has significant levels of autonomy to manage their resources, provide for their subsistence and manage their income" (Garzón Vergara,2014).

Although there is evidence of alleged links between some leaders of MS-

In October 2012, the Department of the Treasury of United States appointed MS-13 as a Transnational Criminal Organization on the grounds that the gang was involved in cross-border criminal activities, including international drug trafficking. Rating that puts this camera at the same level as Los Zetas, Italian Camorra and Japanese Yakuza. See: Sáiz, 2012 
13 and Barrio 18 structures of drug trafficking, the truth is gangs as a whole have not decided to get involved in these criminal networks, rather it is active members or former members who are recruited sporadically to provide certain services to drug cartels such as Los Zetas and Sinaloa Cartel". Thus, "maras are inserted into transnational criminal networks as intermediaries between the main players in drug trafficking" (Farah, 2012, p.57), being responsible, for example, protects shipments "from the ports to the interior of the sub region by land, which gave rise to calls transportistas networks" (Farah, 2012, p.59).

From this perspective, the role of gang members appears to have "becomes important product atomization resulting from the war on drugs, in a form of outsourcing" (Santamaría, 2014, p.4) but these continue to occupy a secondary role in transnational criminal economy. In large part, this is because Mexican cartels conceive Central American gangs as unsophisticated and unable to solve the problems involved in the management of drug trafficking groups because they have a more localized and relaxed activity in "the appearance of its members, particularly their facial tattoos denoting allegiance to a specific camera, making them unsuitable for public interactions in operations requiring low profile" (TNI, 2012, p.8). Indeed, the tactics employed by some kidnappings extortions- like cells and demonstrate the lack of discipline and professionalism of criminal gangs, which reinforces the reluctance of Mexicans to establish sustainable links with them posters.

On the other hand, it has stated that the Central American gangs are strengthening and may control the operations of drug trafficking in the sub region to eventual decline of the main Aztec criminal organizations. In 2012 the current Assistant Secretary of State of the Bureau of International Narcotics and Law Enforcement Affairs, William Brownfield, during a conversation with the Colombian newspaper El Tiempo, said the following:

Four years ago we started a
multinational effort in Mexico,
dominated by the Mexican
government, and what do we see
today? In my opinion, we are seeing

A exceptional case is Moris Alexander Bercián Manchón, alias the Barney - located in the high hierarchy of the MS - who is involved in the transport and distribution of drugs, possibly in the transnational environment, as well as homicides, and possibly, money laundering, being mentioned in a press release from the Treasury Department about gangs: "Bercián Manchón has been involved in drug trafficking operations on behalf of the criminal organization". Indeed, its possible allies include Texis Cartel and Los Zetas while his main enemy is Barrio 18. In both his ability to establish a transnational network of drugs has been possible thanks to his father, a former Colonel in the Guatemalan army, which allegedly has links with some of the most powerful figures in the Central American underworld. See: Dudley, 2013 
the beginning of the end with the beheading of posters and reducing its operating capacity [...] they felt the pressure from the authorities and their response was violence. What we know today - we didn't know then--is that this was the signal of an organization on the verge of collapse due to the pressure sustained on operations in the region. (Vega, 2012)

Thus, the more interaction there between cartels and gangs, both players will have more opportunities to engage in a symbiotic relationship. Under this logic, the gangs could advance their criminal agenda and increase their level of professionalism criminal, which would allow them to acquire greater prominence in the movement of drugs to the detriment of the Aztecs criminal groups. Giving way to a similar situation that occurred in Colombia during the late 80's and early 90's: as the government eroded the capacities of the major cartels -Medellin and Califrom their Mexican counterparts were increasing their power and influence on cocaine trafficking to the United States to take its role in the geopolitics of drugs. This is how the Colombian organized crime today seems to be just a supplier of Mexican cartels.

And while recent statement from the Treasury Department of the
United States uncovered that the gang participation in drug trafficking operations in the sub region has expanded as "clicas [or gangs] local follow international guidelines established by the group's leaders to make strategic decisions involving moves into new territories and recruiting new members" (Cawley, 2013a), added have joined gaining presence by charging a tax of war transportistas circulating through their territories ${ }^{10}$. However, the idea that criminal gangs form a complex network that achieves take control of key links of drug trafficking -snatching control of the routes to transportistas and Mexican drug traffickers- it is impractical given their poor organizational sophistication expressed in the lack of "means, the knowledge, the contacts, the capacity to accumulate capital, and the ability to use that capital to expand their businesses. They are simply focused organizations ensure their subsistence" (Dudley, 2013b).

Another reason lies in the sporadic and opportunistic gangs linking with a specific Mexican cartel, in the case of Guatemala with Los Zetas in Honduras with the Sinaloa Cartel and Salvadoran soil with Texis Cartel or failing to Los Perrones. As in any economy -licit or illicitly- relationships with suppliers, transport agents and buyers are not

\footnotetext{
10 Statistics suggest that the northern triangle is the epicenter of global extortion, is how Salvadorans paid about US $\$ 400$ million a year by extortion gangs, followed by Hondurans, who paid about US $\$ 200$ million, and Guatemalans, with around US \$61 million. See: Dudley, \& Lohmuller, 2015
} 
exclusive, that is, each link is free to form bonds with others in the absence of a common source of authority or sharing of funds. After all, in a commercial supply chain it is easy to replace a link.

Linked to this, the displacement of the criminal operations of the Northern Triangle Mexico has resulted in a shift in gears underground economy as drug trafficking organizations tend to use illicit substances as a means of payment for their services gang members (Dudley, 2012b), then these contract workers directly consume or sell drugs on the streets, which also contributes to their involvement in trafficking networks is residual.

Also for this replacement it would need to materialize that gangs increase their presence in Mexico -which until now only restricted to Baja California, Tamaulipas, Chihuahua and Chiapas(Vega, 2012), will be more difficult than it was for the Mexican cartels migrate to the Northern Triangle because the Aztec government has a high degree of institutional strength in relation to the countries in this sector in Central America because, as noted at beginning of this work, Mexican drug trafficking organizations knew precisely exploit state weakness that characterizes this geographical area to develop their illicit trafficking.

From another angle, it has warned that aggressive anti-gang policies executed in the North triangle have caused several members of maras opt to start operations in other countries of Central America (Daugherty, 2015). That is, they are producing one second cockroach effect. As a recent report of the Judicial Investigation Agency of Costa Rica-Organismo de Investigación Judicial-, members of street gangs Barrio 18 and MS they have expanded their presence in the country since the mid of the last decade. Thus, Costa Rica could become their next hiding place for the following reasons (Gagne, 2015b):

Some Mexican transnational criminal organizations such as the Sinaloa Cartel they have been active in Costa Rica from some years ago, So its presence can facilitate their growth.

The growing importance of the country as a transit point has promoted a growing local drug market offering huge profits to gangs.

Vulnerability to the judicial system against organized crime could enable them to operate relatively quiet.

Costa Rica doesn't record a history of mano dura approach as applied in the Northern Triangle to fight gangs.

\section{Bad partners? Evaluating a partnership between Los Zetas and Mara Salvatrucha.}

In the wake of increasing intersection between organized crime activities 
transnational, local criminal groups and gangs in the North Triangle, some authors like Douglas Farah \& Phillips Lum (2013) have raised the alleged existence of a synergy between Los Zetas and Mara Salvatrucha -as a result of the truce that MS-13 and Barrio 18 launched in El Salvador, between 2012 and 2013- but it is not yet clearly sees what and how viable would be such a connection.

In fact, there have been several hypotheses about: Salvadoran authorities point out that "Mara Salvatrucha wants to increase your arsenal of long-range weapons, grenades and drugs for use and to sell. They know that the economic benefit is enormous and Los Zetas, being a foreign group, need their networks to increase their operational level and thus be able to control all activities: legitimate, illegitimate and criminal" (Ruiz-Goiriena, 2012). In that direction, Scott Stewart, an analyst at Strategic Forecasting, says the MS is increasingly willing to work with Los Zetas "the economic power of the criminal organization, allowing it to operate in countries such as El Salvador and reduce it costs to the local market. Thus there is an incentive to cooperate with the organization or risk going out of business altogether" (Associated Press, 2012). Moreover, John Sullivan \& Adam Elkus (2013) argue that a link between Los Zetas and MS-13 could benefit both parties, understood not as a joint venture; rather it would be a strategic alliance -highly unstable certainly-. Thus, while "MS members would gain a wide support network for its operation and expansion, Los Zetas acquires the flexibility and responsiveness of the gang, generating a greater risk to the governments of Central America" (p.9).

However, the differentiated nature of Los Zetas and MS -from the organizational angle and operationallyacts as a potent antibody against a possible strategic alliance between the two criminal organizations (see Table 1). Thus, the anarchy, indiscipline and functional autonomy of the Mara Salvatrucha - in contrast to the high levels of hierarchy, discipline, professionalism and sophistication that characterize Los Zetas - hinder their subordination to a cartel. Indeed, MS13 is a complex organization crossed by hierarchies but also horizontal relationships between cells or clicas that don't necessarily have regular contact - unlike the Mexican criminal organization - resulting structure neofeudal character (Garzón Vergara, 2014). This means that "it sustained by bonds of respect and loyalty in a hierarchy of influence but lacking sophistication allows the organization to a high degree of adaptability to a changing landscape" (Sullivan \& Elkus, 2013, p.8).

While this relative verticality has been functional to enforce a truce that has caused a drastic drop in homicides, it does not apply that has to do with the local support of gangs 
Table 1: Profile Los Zetas vs. Mara Salvatrucha (MS)

\begin{tabular}{|l|c|c|}
\hline & Los Zetas & Maras Salvatrucha (MS) \\
\hline Type criminal organization & Cartel & Gang \\
\hline Hierarchy & High & Medium \\
\hline Structure & Vertical & Mix \\
\hline Cohesion level & High & Low \\
\hline Sophistication level & High & Low \\
\hline Profesionalization level & High & Low \\
\hline Violence level & High & High \\
\hline Criminal activity diversification & High & Low \\
\hline Transnational presence & Medium & High \\
\hline Source: Own production from Dudley, S. 2012C.
\end{tabular}

(Garzón Vergara, 2014). Therefore, as previously it indicated, "each clica enjoys a significant degree of autonomy to engage in business deemed suitable methods deemed appropriate for survival" (Sullivan \& Elkus, 2013, p.8). However, this highly decentralized structure rather restricts the possibilities of achieving a strategic agreement with Los Zetas.

In contrast, transient and instrumental facilitate cooperation between the Zetas and the cells of the Mara Salvatrucha, since the latter could provide services in the form of mercenary soldier's base. Although such a provision could be provided by other criminal act devoid of baggage associated with members of the MS13 as the side with the members of that gang, Los Zetas are automatically would make a powerful enemy: the Barrio 18, finding himself involved in a vicious gang war that obstruct the development of their activities. Add to that the fact that the provision of the MS as a whole in the Mexican drug trafficking organization certainly would impact on the feasibility of the agreements reached at the cellular level adds. Since each clica is independent, a contract with may not necessarily be respected by the others. For example, ensure the free movement along a route located in a controlled by the Mara Salvatrucha could mean negotiate and maintain a series of agreements with multiple partners' unreliable territory.

In addition, the interpretations of a link between non-state armed actors completely ignored the "identification of a criminal organization lies in family rituals or -derived occupational ties, ethnic and religious-that configure a hallmark against other groups" (Chabat, 2008, p.3). Thus, a franchise is established, "understood not only as a brand but also as a number of methods and know-how to develop 
certain types of activities" (Chabat, 2008, p.5).

In that sense, Villalobos argues that the presence of Mexican cartels in Central America is "part of the coordination between criminal organizations and the use of violence as franchises Los Zetas" (Villalobos, 2011b). Indeed, former armed wing of the Gulf Cartel has followed a peculiar mode of diffusion as the Northern Triangle "nor they have only been coordinated with local criminal organizations, they have developed a model of transplantation" (Santamaría, 2013, p.70). Particularly in Guatemala, Los Zetas have successfully expanded the scope of its operations "by incorporating local actors as members of his organization, the paradigmatic expression of this model are the recruitment of Kaibiles" (UNODC, 2012, p.15). From this perspective, the existence of a military training and a similar code of conduct between Kaibiles and Los Zetas may have facilitated the spread and eventual transplantation of this organization in Guatemala.

Although the preferences share violent methods seem to be a good incentive for cooperation between the Zetas and MS. The truth is that a synergy as described -under the model of transplantation- It is inapplicable to the case of the MS-13 as this camera has its own franchise based on complex initiation rituals through which the will of the applicants to belong to it, expressed in tattoos that identify them as part of that band is confirmed. Thus, this feature of the MS franchise, It makes "a highly visible group whose movements are closely monitored by the authorities" (Chabat, 2008, p.9) i.e. which would imply a high risk to the operations of Los Zetas operations ${ }^{11}$.

Indeed, "the existence of a MS-13 brand is evident with the emergence of bands that use the franchise in Mexico, which have copied the structure and modus operandi of the original version" (Chabat, 2008, p.9). Therefore, "the structure reproduces itself in other companies with similar conditions -high poverty, marginalization, inequality and lack of economic opportunity- through know-how; inevitably it manages information across national borders" (Chabat, 2008, p.10). This situation has affected "There is no intent to monopolize or structure of the MS-13 or criminal activities; by contrast, it has cooperated with copies to carry out its operations in Mexico" (Chabat, 2008, p.11).

11 According to a report prepared by Procuraduría General de República - PGR - Los Zetas employees have emulated directly beheading tactics by the MS, product of indoctrination and training provided by the gang, with the aim of intimidating opponents, confirm their presence at the site, and earn rankings within the criminal organization. See: Vega, 2012 
And although It has said that the Aztec paramilitary organization seeks to assimilate members of one of the most violent factions of the MS-13, Fulton Locos Salvatruchas -FLSand Hollywood Locos Salvatruchos - HLS - by ideological indoctrination (Ruiz-Goiriena, 2012). Version would be endorsed by the existence of training camps Los Zetas located in the region of Peten, Guatemala with "mobile camps in nearby San Salvador volcano in territory once controlled by the FMLN" (Farah, 2012, p.62). The truth is that it would be difficult to persuade members of the MS leaving his brothers to join another criminal organization with strong territorial roots as Los Zetas as it would require a complete reorientation of their values.

\section{Conclusions}

The War on Drugs driven Mexico during the government of Felipe Calderon (2006-12) it has been identified as the main catalyst for the shift to the North Triangle -Guatemala, Honduras and El Salvador- producing so called cockroach effect. This new scenario shows that the partial victories of a given nation may become a failure for your neighbors.

The recent emergence of major Mexican cartels -Sinaloa and Los Zetas- in the sub region evidence both his desire to expand into new markets and find a refuge from the escalating Mexican authorities. Due to its geographical location -among the largest cocaine producer and the largest consumer of it worldwide-, its porous borders, weak institutions and increasing sophistication of local criminal groups -transportistas- and gangs, the area offers ample opportunities for Mexican drug cartels expansion.

However, Mexican cartels have not only taken to Northern Triangle operations to traffic cocaine into the United States, but their battles for control of the streets located in this geographic area, which are fought by local criminal organizations, leading to various degrees of cooperation between non-state actors as the role of each country in the geopolitics of drugs. Thus, as criminal organizations are facing greater pressure, they seek new allies, and are associated with actors that are further down the chain to help them with the dirty work and protect their interests: diversify income sources and smuggling routes.

In this regard, the adoption of policies hard hand against street gangs in the Northern Triangle, coupled with the expansion of drug trafficking networks in the sub region, it had an unexpected effect: Increasing intersection between the activities of transnational organized crime -Posters Mexicans, -transportistas- local criminal groups and gangs. Although it has been speculated the existence of an alleged synergy between Los Zetas and the Mara Salvatrucha, as a result of the MS-13 and Barrio 18 truce launched in 
El Salvador between 2012 and 2013. The truth is the differentiated nature of both criminal organizations -from the organizational angle and operationallyit acts as a potent antibody against possible strategic alliance.

Thus, the sub region consists of MexicoNorthern Triangle of Central America, connected in turn with the United States has co-dependence dynamics that force us to think solutions to its security dilemma in transnational terms. Paradoxically, the way that many governments are fighting criminal organizations is limited to the local level-the criminal organizations operating in their national territoryand rarely establishes mechanisms to combat transnational phenomenon as design and implement policies that involve transnational exchange of information between governments and sometimes joint action to hit them simultaneously to multiple nodes of transnational network.

Consequently, if the criminal diaspora is a direct-but undesirable- consequence high institutional pressure in certain countries such as Mexico, neighboring States should work in coordination with the aim of halting the expansion of criminal networks by developing mechanisms to contain the cockroach effect. Otherwise the success of a specific country could be seriously compromised by the actions of the same criminal group but this time running from a nearby territory such as Los Zetas in Guatemala.

\section{REFERENCES}

ASSESSMENT CAPACITIES PROJECT (ACAPS), (2014). Otras Situaciones de Violencia en el Triángulo Norte Centroamericano.

Bargent, J. (8 November 2013). Informe de Estados Unidos muestra la corrupción de las fuerzas especiales de Guatemala. Insight Crime Crimen Organizado en las Américas. Retrieved 10 August 2015, from http://es.insightcrime.org/noticiasdel-dia/informe-de-estados-unidosmuestra-la-corrupcion-de-lasfuerzas-especiales-de-guatemala

Bartolomé, M., \& Sampó, C. (2014). Reflexiones sobre el cumplimiento de la tregua entre maras en $\mathrm{El}$ Salvador. Estudios Internacionales, 46(177), 89-106.

Cawley, M. (18 December 2013a). Pandillas de El Salvador se adentran cada vez más en el tráfico de drogas: Policía. Insight Crime Crimen Organizado en las Américas. Retrieved 12 August 2015, from http://es.insightcrime.org/noticiasdel-dia/pandillas-de-el-salvadorse-adentran-cada-vez-mas-en-eltrafico-de-drogas-policia

Cawley, M. (20 August 2013b). ¿Son los países del Triángulo del Norte «Narco-Estados〉?. Insight Crime Crimen Organizado en las Américas. Retrieved 28 July 2015, from http://es.insightcrime.org/ analisis/los-paises-del-triangulodel-norte-narcoestados 
Chabat, J. (2008). Franchises for Crime: "Maras" and North American Security. México City: CIDE.

Daugherty, A. (29 April 2015). 'Pandilleros de El Salvador huyen a Honduras y Guatemala'. Insight Crime Crimen Organizado en las Américas. Retrieved 12 August 2015, from http://es.insightcrime. org/noticias-del-dia/pandillerosde-el-salvador-huyen-a-hondurasy-guatemala

Dudley, S. (2012a). Transnational Crime in México and Central America: Its Evolution and Role in International Migration. Washington DC: Migration Policy Institute.

Dudley, S. (28 November 2012b). Pandillas, Deportaciones y Violencia en Centroamérica. Insight Crime Crimen Organizado en las Américas. Retrieved 12 August 2015, from http://es.insightcrime. org/investigaciones/parte-iipandillas-deportaciones-yviolencia-en-centroamerica

Dudley, S. (17 April 2012c). Reports of Zetas-MS-13 Alliance in Guatemala Unfounded. Insight Crime Organized Crime in the Americas. Retrieved 4 August 2015, from http://www.insightcrime.org/ investigations/reports-of-zetasms-13-alliance-in-guatemalaunfounded

Dudley, S. (16 September 2013a). EI nuevo narcomapa de Guatemala: Menos Zetas, el mismo caos. Insight Crime Crimen Organizado en las
Américas. Retrieved 16 March 2016, from http://es.insightcrime. org/analisis/el-nuevo-narcomapade-guatemala-menos-zetas-elmismo-caos

Dudley, S. (11 June 2013b). 'El Barney' de la MS13: ¿Tendencia o caso aislado?. Insight Crime Crimen Organizado en las Américas. Retrieved 12 August 2015, from http://es.insightcrime.org/ investigaciones/el-barney-de-lams-13-tendencia-o-caso-aislado

Dudley, S., \& Lohmuller, M. (2 July 2015). Triángulo del Norte, epicentro mundial de la extorsión. Insight Crime Crimen Organizado en las Américas. Retrieved 12 August 2015, from http:// es.insightcrime.org/noticias-deldia/triangulo-norte-epicentromundial-extorsion

Farah, D. (2012). Central America's Gangs: Changing Nature and New Partners. Journal Of International Affairs, 1(66), 53-67.

Farah, D. (2013). Central America's Northern Triangle: A Time for Turmoil and Transitions. Prism, 4(3), 88-109.

Farah, D. \& Lum, P. (2013). Central American Gangs and Transnational Criminal Organizations: The Changing Relationships in a Time of Turmoil. International Assessment and Strategy Center.

Fox, E. (15 November 2012). ¿Podrían las Pandillas Centroamericanas 
Usurpar el Papel de los Carteles Mexicanos?. Insight Crime Crimen Organizado en las Américas. Retrieved 10 August 2015, from http://es.insightcrime.org/ analisis/podrian-las-pandillascentroamericanas-usurpar-elpapel-de-los-carteles-mexicanos

Gagne, D. (22 July 2015a). Los mejores escondites de El Chapo fuera de México están en países vecinos. Insight Crime Crimen Organizado en las Américas. Retrieved 12 August 2015, from http://es.insightcrime. org/analisis/mejores-esconditesel-chapo-extranjero-estan-paisesvecinos

Gagne, D. (16 June 2015b). ¿Es Costa Rica el próximo destino de las maras?. Insight Crime Crimen Organizado en las Américas. Retrieved 12 August 2015, from http://es.insightcrime.org/noticiasdel-dia/costa-rica-proximodestino-maras

Garzón, J. (2013). La Diáspora Criminal: La difusión transnacional del Crimen Organizado y cómo contener su expansión. In J. Garzón \& E. Olson, La Diáspora Criminal: La difusión transnacional del Crimen Organizado y cómo contener su expansión, (1st ed., pp. 1-25). Washington, DC: Latin American Program Woodrow Wilson International Center for Scholars.

Garzón, J. (3 April 2014). Redimensionando la relación entre las Maras de El Salvador y el narcotráfico. Insight Crime Crimen Organizado en las Américas. Retrieved 11 August 2015, from http://es.insightcrime.org/analisis/ redimensionando-la-relacionentre-las-maras-de-el-salvador-yel-narcotrafico

International Crisis Group (ICC), (2011). Guatemala: Drug Trafficking and Violence. Bruselas.

International Crisis Group (ICC), (2014). Corredor de violencia: la frontera entre Guatemala y Honduras. Bruselas.

Martinez, P. (2 July 2013). Mapa Centroamericano... De los Cárteles Mexicanos. Insight Crime Crimen Organizado en las Américas. Retrieved 10 August 2015, from http://es.insightcrime.org/analisis/ mapa-centroamericano-de-loscarteles-mexicanos

Mc Dermott, J. (5 Febraury 2013). Los Zetas se establecen en Honduras. Insight Crime Crimen Organizado en las Américas. Retrieved 11 August 2015, from http:// es.insightcrime.org/analisis/loszetas-se-establecen-en-honduras

Oficina de Naciones Unidas contra la Droga y el Delito (UNODC), (2012). Delincuencia Organizada Transnacional en Centroamérica y el Caribe: Una Evaluación de las Amenazas. Viena.

Pachico, E. (5 March 2013). 'MS13 Trabajando con Narcotraficantes 
Internacionales'. Insight Crime Crimen Organizado en las Américas. Retrieved 13 August 2015, from http://es.insightcrime.org/ analisis/ms-13-trabajando-connarcotraficantes-internacionales

Parkinson, C. (3 Octuber 2013a). Tácticas criminales de México migran a Honduras. Insight Crime Crimen Organizado en las Américas. Retrieved 12 August 2015, from http://es.insightcrime.org/noticiasdel-dia/tacticas-del-crimen-enmexico-migran-a-honduras

Parkinson, C. (11 Octuber 2013b). Alijo de armas en El Salvador expone vínculo entre el Cartel de Texis y los Zetas. Insight Crime Crimen Organizado en las Américas. Retrieved 11 August 2015, from http://es.insightcrime.org/noticiasdel-dia/alijo-de-armas-en-elsalvador-expone-vinculo-entre-elcartel-de-texis-y-los-zetas

Perez Ventura, J. (5 Febraury 2014). EI camino de la droga. El orden mundial en el S.XXI. Retrieved 10 August 2015, from http://elordenmundial. com/regiones/latinoamerica/elcamino-de-la-droga/

Press, A. (6 April 2012). Los Zetas reclutan miembros de la Mara Salvatrucha, dicen autoridades de Guatemala. Animal Politico. Retrieved 13 August 2015, from http://www.animalpolitico. com/2012/04/los-zetas-reclutanmiembros-de-la-mara-salvatruchadicen-autoridades-de-guatemala/
Ramsey, G. (12 November 2012). Informe destaca la lucha en el Triángulo del Norte por asegurar sus porosas fronteras. Insight Crime Crimen Organizado en las Américas. Retrieved 13 August 2015, from http://es.insightcrime. org/analisis/informe-destaca-lalucha-en-el-triangulo-del-nortepor-asegurar-sus-porosas-fronteras

Ruiz-Goiriena, R. (9 April 2012). Los Zetas y las maras, una temible alianza. La Nacion. Retrieved 13 August 2015, from http://www. lanacion.com.ar/1463380-loszetas-y-las-maras-una-temiblealianza

Sáiz, E. (11 Octuber 2012). EE UU designa a la mara Salvatrucha como organización criminal internacional. El País Internacional. Retrieved 12 August 2015, from http://internacional.elpais. com/internacional/2012/10/11/ actualidad/1349984891_307336. html

Santamaría, G. (2013). La difusión y contención del crimen organizado en la subregión MéxicoCentroamérica. In J. Garzón \& E. Olson, La Diáspora Criminal: La difusión transnacional del Crimen Organizado y cómo contener su expansión (1st ed., pp. 59-100). Washington, DC, Latin American Program Woodrow Wilson International Center for Scholars.

Santamaría, G. (2014). Drugs, Gangs and Vigilantes: How to tackle the 
New Breeds of Mexican Armed Violence. Norwegian Peace Building Resource Centre.

Servitja Roca, X. (2012). El crimen organizado en México y el 'Triángulo norte' durante el mandato de Felipe Calderón. Madrid: Instituto Español de Estudios Políticos y Estratégicos (IEEE).

Sullivan, J., \& Elkus, A. (2013). Los Zetas and MS - 13: Untraditional Alliances. CTC Sentinel.

TRANSNATIONAL INSTITUTE (TNI), (2012). El nexo entre drogas y violencia en el Triángulo del Norte. Amsterdam: Open Society Foundations.

Vega, A. (22 July 2012). Maras adiestran a cárteles mexicanos; decapitaciones, aprendidas de pandillas: PGR. Excélsior. Retrieved 19 August 2015, from http://www. excelsior.com.mx/2012/07/22/ nacional/849193

Vega, W. (20 Octuber 2012). 'Crisis de Centroamérica se va a mover al Caribe': William Brownfield. El Tiempo. Retrieved 15 August 2015, from http://www.eltiempo. com/archivo/documento/CMS12319523

Villalobos, J. (2011a). De Los Zetas al Cartel de La Habana. Foreign Affairs Latinoamérica, 11(2), 10-21.

Villalobos, J. (20 June 2011b). Centroamérica: Zetas, maras y violencia. El País Internacional. Retrieved 13 August 2015, from http:// internacional.elpais.com/ internacional/2011/06/20/ actualidad/1308520813_850215. html 